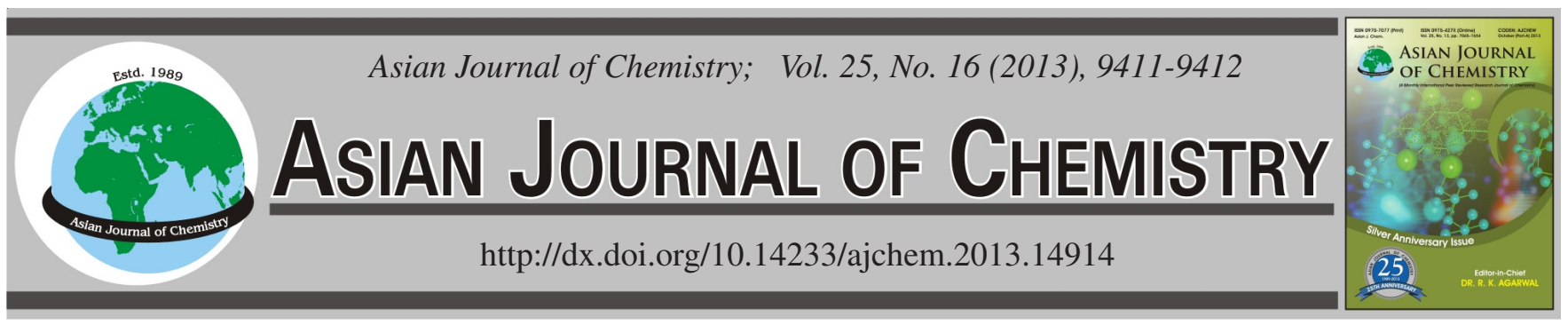

NOTE

\title{
Study on the Content of Beneficial Elements, Harmful Elements and Rare Earth Elements in the Wild Soybean (Glycine soja) by ICP-MS
}

\author{
HongXing Zhang ${ }^{1, *}$ and YukUI Rui ${ }^{2}$
}

${ }^{1}$ Beijing Key Laboratory of Agricultural Product Safety Detection and Control, Department of Food Science, Beijing University of Agriculture, Beijing 102206, P.R. China

${ }^{2}$ College of Resources and Environmental Sciences, China Agricultural University, Beijing 100193, P.R. China

*Corresponding author: Fax: +86 10 80799170; Tel: +8610 80794124; E-mail: zhanghx511@ gmail.com

Key Words: Wild soybean (Glycine soja), Trace elements, Heavy metals, ICP-MS.

Wild soybean (Glycine soja) belongs to Leguminosae, Papilionoideae, Glycine, Soja. The soybean (Glyci ne max) originated in China and annual wild soybean (Glyci ne soja), which has many excellent characteristics of high protein, strong resistance and high breeding coefficient, is wild relatives of cultivated soybean. Wild soybean is the important sources of genes to improve cultivated soybean varieties and is also valuable resource for research of soybean origin, evolution, classification. Distribution region of wild soybean is very narrow in the world, only distributed in non-arid temperate regions in East Asia, including China, the Korean Peninsula, Japan, the Russian Far East, Sakhalin, the Kuril, etc. ${ }^{1}$.

China has the most wild soybean resources in the world, now national Gene Bank collected and preserved more than 6500 copies of wild soybean resources, which accounts for $90 \%$ of the world-wild soybean resources. Wild soybean was included in the national key protected wild plants as the second class state protection object in $1999^{2}$.

Many researches have studied the organic composition in wild soybean, such as isoflavones, protein and lipoid content ${ }^{3}$ and crude fiber, total sugar, calcium, magnesium, total falconoid, total free amino acids, $\mathrm{Zn}$ and $\mathrm{Cu}^{4}$.

Trace element nutrition in wild soybean from Beijing has been less reported, especially heavy metals, trace elements and rare earth elements. This work is to study the nutritional and safety characteristics of total elements to provide basis of food development and application of wild soybean.

Wild soybean (Glycine soja) was collected from Shangzhuang experimental station of China Agricultural University, Haidian district of Beijing city, China. The samples were washed with deionized water, dried and grinded, digested concentrated nitric acid and $30 \% \mathrm{H}_{2} \mathrm{O}_{2}$ solution, finally determined by ICP-MS, the ICP-MS instrument is Thermo-X7 produced by Thermo Electron Corporation of USA.

Macroelements in Glycine soja: The results show that wild soybean contain much macroelements $\mathrm{Mg}, \mathrm{P}, \mathrm{K}, \mathrm{Ca}$ and $\mathrm{Mn}$ (Table-1), but the concentrations $\mathrm{Mg}, \mathrm{P}, \mathrm{K}$ and $\mathrm{Ca}$ are much lower than those in cultured soybean in northeast of China, the concentrations of $\mathrm{Mn}$ and $\mathrm{Fe}$ have no any significant difference ${ }^{5}$.

Beneficial trace elements in Glycine soja: Beneficial trace elements $\mathrm{Se}, \mathrm{Co}$ and Mo in wild soybean are significantly higher than that in cultured soybean, so wild soybean can supplement Se, Co and Mo for human health. The contents of $\mathrm{Li}$ and $\mathrm{Zn}$ in wild soybean were similar to cultured soybean ${ }^{5}$. The descending order of beneficial trace elements in wild soybean from Beijing is $\mathrm{Zn}>\mathrm{Mo}>\mathrm{Se}>\mathrm{I}>\mathrm{Co}>\mathrm{Li}$.

Harmful trace elements in Glycine soja: This research proved that wild soybean contained much $\mathrm{Al}, \mathrm{Cu}$ and $\mathrm{Ni}$, but all heavy metals did not exceed the national standards ${ }^{6}$. 
TABLE- 1

CONCENTRATIONS OF MACROELEMENTS

IN Glycine soja (ng/g)

\begin{tabular}{cc|cc}
\hline Elements & Concentration & Elements & Concentration \\
\hline $\mathrm{Mg}$ & 884784.63 & $\mathrm{Ca}$ & 1395794.52 \\
$\mathrm{P}$ & 4440612.63 & $\mathrm{Mn}$ & 22151.83 \\
$\mathrm{~K}$ & 4843361.11 & $\mathrm{Fe}$ & 69936.07 \\
\hline
\end{tabular}

TABLE-2

CONCENTRATIONS OF BENEFICIAL

TRACE ELEMENTS IN Glycine soja (ng/g)

\begin{tabular}{cc|cc}
\hline Elements & Concentration & Elements & Concentration \\
\hline $\mathrm{Li}$ & 7.23 & $\mathrm{Zn}$ & 19312.40 \\
$\mathrm{I}$ & 470.70 & $\mathrm{Se}$ & 796.04 \\
$\mathrm{Co}$ & 167.81 & $\mathrm{Mo}$ & 2045.66 \\
\hline
\end{tabular}

TABLE-3

CONCENTRATIONS OF HARMFUL

TRACE ELEMENTS IN Glycine soja (ng/g)

\begin{tabular}{cc|cc}
\hline Elements & Concentration & Elements & Concentration \\
\hline $\mathrm{Al}$ & 2954.72 & $\mathrm{Tl}$ & 0.38 \\
$\mathrm{Cr}$ & 56.70 & $\mathrm{~Pb}$ & 28.92 \\
$\mathrm{Ni}$ & 1029.68 & $\mathrm{Cd}$ & 36.91 \\
$\mathrm{Cu}$ & 8850.46 & $\mathrm{Sn}$ & 0.00 \\
$\mathrm{As}$ & 0.76 & $\mathrm{Sb}$ & 0.00 \\
$\mathrm{Hg}$ & 0.00 & - & - \\
\hline
\end{tabular}

Rare earth elements in Glycine soja: This study proved rare earth elements in wild soybean were at a very low level, most of rare earth elements were below $1.00 \mathrm{ng} / \mathrm{g}$ and six kind of rare earth elements are not detected (Tb, Dy, Er, Tm, Yb and Lu) (Table-4).
TABLE-4

CONCENTRATIONS OF RARE EARTH

ELEMENTS IN Glycine soja (ng/g)

\begin{tabular}{cc|cc}
\hline Elements & Concentration & Elements & Concentration \\
\hline $\mathrm{La}$ & 3.42 & $\mathrm{Dy}$ & 0.00 \\
$\mathrm{Ce}$ & 10.65 & $\mathrm{Ho}$ & 0.38 \\
$\mathrm{Pr}$ & 1.90 & $\mathrm{Er}$ & 0.00 \\
$\mathrm{Nd}$ & 5.33 & $\mathrm{Tm}$ & 0.00 \\
$\mathrm{Sm}$ & 0.38 & $\mathrm{Yb}$ & 0.00 \\
$\mathrm{Eu}$ & 1.14 & $\mathrm{Lu}$ & 0.00 \\
$\mathrm{Gd}$ & 0.76 & $\mathrm{Sc}$ & 64.69 \\
$\mathrm{~Tb}$ & 0.00 & $\mathrm{Y}$ & 3.42 \\
\hline
\end{tabular}

\section{ACKNOWLEDGEMENTS}

The project was supported by the National Natural Science Foundation of China (No. 41371471).

\section{REFERENCES}

1. X.H. Li, K.J. Wang and F.S. Li, J. Plant Genetic Resour., 6, 319 (2005).

2. H.M. Yan, Chin. Wild Plant Resour, 26, 37 (2007).

3. S. Zhou, H.R. Sekizaki, Y. Wang, S. Satoko and Z.H. Yang, Soybean Sci., 27, 315 (2008).

4. M.L. Li and L. Zheng, Acta Pratacult. Sin., 20, 137 (2011).

5. P.M. Yan, W.Y. Wang, Y.K. Rui, F.S. Zhang and Y.H. Jin, Spectrosc. Spectral Anal., 27, 162921631 (2007).

6. National Standards of P.R. China: GB 2762-2005. 